Int. J. Morphol.,

33(2):553-557, 2015

\title{
Study of Morphology of Mandibular Canal Through Computed Tomography
}

\author{
Estudio de la Morfología del Canal Mandibular a Través de Tomografía Computadorizada
}

\author{
Carla Cabral dos Santos Accioly Lins*; Raphaelle Lima de Almeida Beltrão** \\ Wilber Fellipe de Lima Gomes ${ }^{* * *}$ \& Márcia Maria Ribeiro****
}

\begin{abstract}
LINS, C. C. S. A.; BELTRÃO, R. L. A.; GOMES, W. F. L. \& RIBEIRO, M. M. Study of morphology of mandibular canal through computed tomography. Int. J. Morphol., 33(2):553-557, 2015.

SUMMARY: This work aimed to study the morphology of the mandibular canal in Computed Tomography (CT scans), in order to assist in the clinical and surgical management of dental interventions in the mandible area. The material used was composed of $377 \mathrm{CT}$ scans, selected by age (between 15 and 80 years), obtained during the period from 2011 to 2013, belonging to a private practice radiology of the city of Caruaru-PE, Brazil. 96 of these met the inclusion criteria, with $37.5 \%$ male and $62.5 \%$ female. Concerning the form of the mandibular canal, all images presented: a single canal, bilateral, extending from the mandibular to the mental foramen, without any morphological change. $37.5 \%$ had mandibular canals classified as type I, 22,92\% canals type II and III and 16,66\% canals type IV. Thus, we emphasize the importance of knowing the anatomy of the mandible as well as the path of the inferior alveolar nerve by the mandibular canal, especially to perform the various procedures that are performed in this region in order to minimize injury to the neurovascular bundle.
\end{abstract}

KEY WORDS: Anatomy; Mandible; Computed tomography.

\section{INTRODUCTION}

The knowledge of the morphology and topography of the mandibular canal is important for the performance of dental procedures in the mandible, because it involves important anatomical structures for Dentistry (Lindh et al., 1995; Xie et al., 1996). It is located inside the body of the mandible, originating from the mandibular foramen and extends through the mental foramen, giving passage to the inferior alveolar nerve, artery and vein (Madeira, 1995); It has been widely studied with respect to their location and its path as well as the possible variations in normal anatomy since they can have different configurations (Neves et al., 2009).

In third molar removal surgeries, placement of dental and orthognathic implants, the mandibular canal is used as a reference structure to prevent the occurrence of injuries to the inferior alveolar nerve (Blaeser et al., 2003; Fontoura et al., 2002). Its radiographic appearance is described as a radiolucent band of uniform thickness, limited by two radiopaque walls in most cases, but may differ in alternating bands of radiolucency and radiopacity due to the number and distribution of trabecular bone around the neurovascular bundle canal of the mandible (Xie et al., 1997; Wadu et al., 1997).

Panoramic radiographs are widely used to evaluate the relationship between the molars, especially third molars, and the mandibular canal. However, this imaging modality provides limited information about the buccolingual position of the canals. Currently, new technologies have contributed to enhance diagnostic techniques allowing a thorough and accurate evaluation of the anatomical structures of the mandible. Among them, there is the CT scan, which is one of the great advances of our time in the image area (Rodrigues \& Vitral, 2007).

The computed tomography enables biplane acquisition with three-dimensional reconstructions, with extreme reliability, allowing for accurate metric parameters of the mandibular canal and its relations with other

PhD, Professor of the Department of Anatomy, Federal University of Pernambuco, Recife-PE, Brazil.

** Oral and Maxillofacial Surgeon, Specialist in Morphology, Federal University of Pernambuco, Recife-PE, Brazil.

***** Student of Odontology, Federal University of Pernambuco, Recife-PE, Brasil.

***** Dentistry, Specialist in Radiology, Caruaru-PE, Brasil. 
anatomical accidents of the mandible (Parks, 2000; Arellano, 2001; Neves et al., 2014). Thus, this work aimed to study the morphology of the mandibular canal in helical CT scans, in order to assist in clinical and surgical management of dental interventions in the mandible area.

\section{MATERIAL AND METHOD}

This research was submitted to the Ethics Committee of the Center of Health Sciences, of the Federal University of Pernambuco, and approved by $\mathrm{N}^{\circ}$. 02856112.7.0000.5208. The material used was composed of 377 CT scans, selected by age (between 15 and 80 years) in the period from 2011 to 2013 , belonging to a private practice radiology of the city of Caruaru-PE, Brazil. The CT scans were used to evaluate the shape, the mandibular canal, and classify its height in relation to the roots of the 1st and 2nd molars. Inclusion criteria were: to allow complete visualization of the mandibular canal, and having the presence of the second molars bilaterally, in their absence first molars were used, and the images of the ones subjected to surgery or any other pathology of the mandible were excluded.

In the study an apparatus CT Philips, Model \#CT99 BrightSpeed SIS 16 channels (Holland, Roterdã/2011) was used. The cutting parameters were: tube voltage $120 \mathrm{kV}$, tube current: $180 \mathrm{~mA}$, collimation $16 \times 0.625 \mathrm{~mm}$, and pitch of 0.562 . These parameters were determined by the best low ratio dose and image quality.

The images were acquired in the supine position with the cutting plane parallel to the occlusal plane. The axial images were reconstructed with $0.625 \mathrm{~mm}$ thickness and $0.310 \mathrm{~mm}$ increments using bone filter. OsiriX 5.6 program was used for reformatting images, through the recovery of server images, one MPR curve (multiplanar reconstruction) was performed on available axial images. This reformatting curve was performed in multiple planes where the mandibular canal and its relations with the inferior mandibular cortex and apex of the roots of the first or second molars were identified. The measurement was always performed in the oblique sagittal plane, taking into account the parameters of classification by Nortjé et al. (1977): mandibular canals Type I: single, high, bilateral, distant up to $2 \mathrm{~mm}$ from the root apex of the mandibular second molar and in its absence, the first molar; Type II: single, intermediate, bilateral, not fulfilling the criteria to be classified as high or low; Type III: single, low, bilateral, distant up to $2 \mathrm{~mm}$ from the cortical margin of the mandible, and finally, Type IV canals: variations including asymmetries, duplication or absence of mandibular canal.

\section{RESULTS}

From the CT scans analyzed, 96 did not fit within the criteria of inclusion and exclusion. From this total, 37.5\% were male and $62.5 \%$ female. Concerning the form of the mandibular canal, all images presented: single, bilateral channel, extending from the mandible to the mental foramen, without any morphological change.

It was observed that $37.5 \%$ of the images had mandibular canals classified as type I: single, high, bilateral, distant up to $2 \mathrm{~mm}$ from the root apex of the first or second molar (Fig. 1). Followed by type II: single, intermediate, bilateral, not fulfilling the criteria to be classified as high or low (Fig. 2) and type III: single, low, bilateral, distant up to $2 \mathrm{~mm}$ from the cortical margin of the mandible (Fig. 3) where it was observed the same prevalence (22.92\%), and, finally, type IV canals: variations including asymmetries, duplication or absence of mandibular canal, of which only asymmetric canals were observed,with the lowest prevalence (16.66\%).

\section{DISCUSSION}

Technological advances have contributed to enhance diagnostic techniques allowing a thorough and accurate evaluation of body structures. Among them, CT has stood out to be an important tool for visualization of anatomic structures and pathologies in three dimensions with better resolution (Bueno et al., 2007). Among its advantages stands out better planning of surgery facilitating patient information about the procedure and the risks related to it. As disadvantages we consider the radiation dose to which the patient is subjected and the cost of the procedure (Koong et al., 2006; Ohman et al., 2006; Friedland et al., 2008; Jhamb et al., 2009; Dalili et al., 2011).

Research with radiographic images approach, has focused on the mandible in order to obtain information about morphology of the mandibular canal and thereby assisting the practice of the dentist. The extraction of third molars is one of the most common procedures among oral surgery and many complications can occur if an adequate preoperative planning is not carried out.

The neurological complications of surgical removal of impacted third molars may arise from an incomplete diagnosis of the surrounding anatomical structures or surgical technique. The incidence of these complications ranges from $0.2-1 \%$ for permanent injury and $3.3-13 \%$ for a temporary 


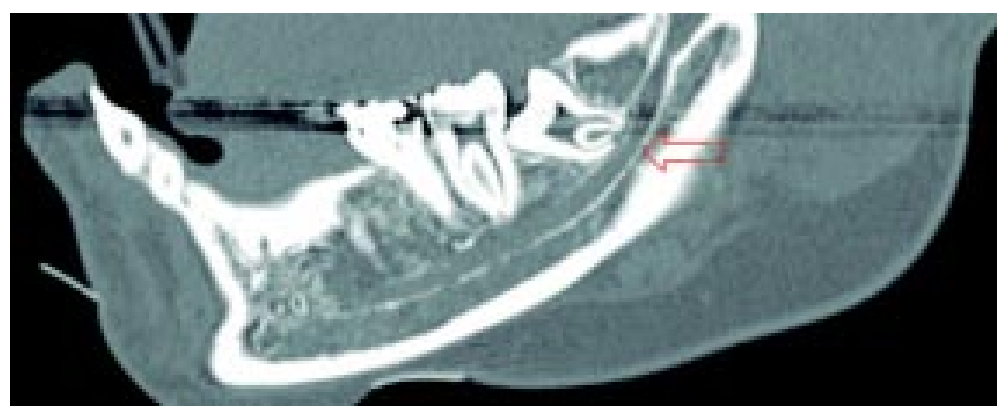

Fig. 1. Imaging aspect of the mandibular canal type I.

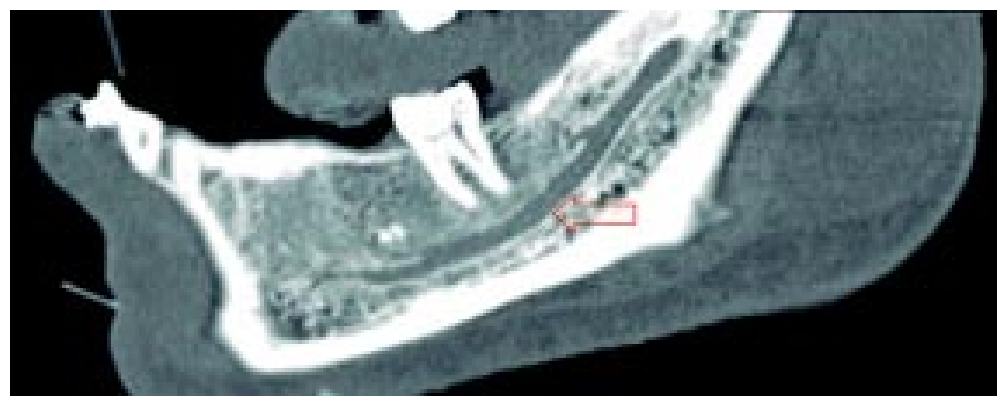

Fig. 2. Imaging aspect of the mandibular canal type II.

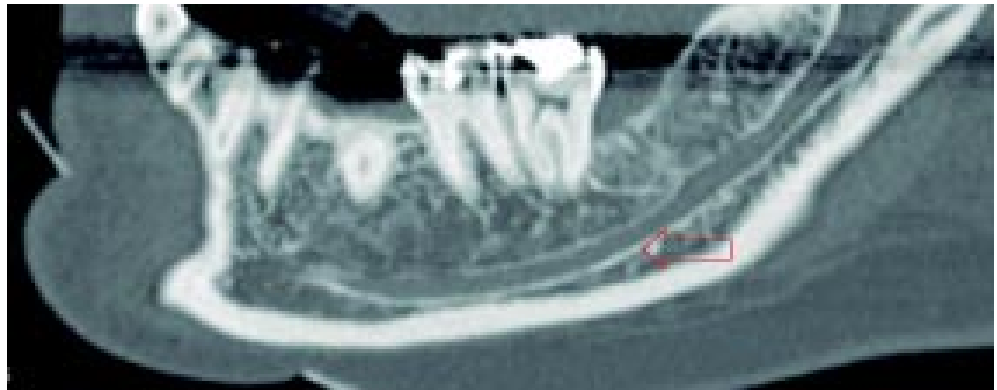

Fig. 3. Imaging aspect of the mandibular canal type III.

injury (Brann et al., 1999; Gülicher \& Gerlach, 2000; Strietzel \& Reichart, 2002). The damage to the mandibular nerve increases to $30 \%$ when there is a close relationship between the third molar and the mandibular canal (Öhman et al.).

An important property of tomographic images is the ability to determine the direction of the dislocation and extraction of molars, which in most cases cannot be done using only a panoramic radiograph. Most injuries to the inferior alveolar nerve after extraction are the result of compression and tension of the nerve through the movements of roots of the molar (Rood, 1992).

In literature, no works were found that classify the height of the mandibular canal in relation to the roots of mandibular molars in CT scans, thus in this study we used the same parameters of panoramic radiographs (Nortjé et al.; Langlais et al., 1985; Devito \& Tamburús, 2001). In these studies it was observed a higher prevalence of type I canals and the lowest of type IV canals, these data resemble those obtained in this study.

Concerning the form of the mandibular canal, no morphological changes were observed, however these findings differ from studies of Sanchis et al. (2003) and Rouas et al. (2007) who found a double mandibular canals; Auluck \& Pai (2005) who reported a case of mandibular trifid canal, unilateral, and Clays \& Wackens (2005) who described a case of two mandibular canals, unilateral rights, starting from the distinct mandibular foramina and ending in separate foramina.

The absence of the cortical bone of the mandibular canal on computed tomography is a radiographic sign suggestive of exposure of the inferior alveolar nerve (Nakamori et al., 2008; Jhamb et al.). This finding corroborates the study of Tantanapornkul et al. (2007), in which, they detected, by computed tomography, the absence of cortical bone in 25 of 27 cases of exposure of the neurovascular bundle after extraction.

Recent studies have compared the data obtained from panoramic radiographs and CT scans. The authors suggest that the most reliable imaging for planning procedures involving the area of the mandibular canal, with the most accurate view of this structure in three dimensions and safer design of its relationship with the alveolar crest is that obtained by computed tomography (Tantanapomkul et al.; Suomalainen et al., 2010), this happens because panoramic radiographs provide limited information about buccolingual relationship between the mandibular canal and mandibular molars (Dalili et al.). With this, it is worth noting the importance of knowing the anatomy of the mandible as well as the path of the inferior alveolar nerve at the mandibular canal, especially to perform the various procedures that are performed in this region in order to minimize injury to the neurovascular bundle.

\section{ACKNOWLEDGEMENTS}

This study was supported by grants from Universidade Federal de Pernambuco (PIBIC/ UFPE/ CNPq)- Brazil. 
LINS, C. C. S. A.; BELTRÃO, R. L. A.; GOMES, W. F. L. \& RIBEIRO, M. M. Estudio de la morfología del canal mandibular a través de tomografía computadorizada. Int. J. Morphol., 33(2):553-557, 2015.

RESUMEN: El objetivo fue estudiar la morfología del canal mandibular en la tomografía computadorizada (TC), con el fin de ayudar en el manejo clínico y quirúrgico de las intervenciones dentales en el área de la mandíbula. El material utilizado incluyó 377 TC, seleccionadas por edad (entre 15 y 80 años), obtenidas durante el período 2011-2013 desde el banco de datos de una clínica privada de radiología en la ciudad de Caruaru-PE, Brasil. Noventa y seis TC cumplieron los criterios de inclusión (37,5\% hombres y 62,5\% mujeres). En relación a la forma del canal mandibular, todas las imágenes presentaron un solo canal, bilateral, que se extiendió desde el foramen mandibular hasta el foramen mental, sin ningún cambio morfológico. En el 37,5\% de las TC hubo canales mandibulares clasificados como Tipo I; en 22,92\% tipo II y III. Sólo el 16,66\% presentó canales tipo IV. Destacamos la importancia de conocer la anatomía de la mandíbula, así como el trayecto del nervio alveolar inferior en el canal mandibular, especialmente para la realización de los diversos procedimientos en esta región con el fin de minimizar el daño a los haces neurovasculares.

PALABRAS CLAVE: Anatomía ; Mandíbula; Tomografía computadorizada.

\section{REFERENCES}

Arellano, J. C. V. Computed tomography in the diagnosis and control of the TMJ malfunction treatment. J. Bras. ATM Oclusão Dor Orofac., 1(4):315-23, 2001.

Auluck, A. \& Pai, K. M. Trifid mandibular nerve canal. Dentomaxillofac. Radiol., 34(4):259, 2005.

Blaeser, B. F.; August, M. A.; Donoff, R. B.; Kaban, L. B. \& Dodson, T. B. Panoramic radiographic risk factors for inferior alveolar nerve injury after third molar extraction. J. Oral Maxillofac. Surg., 61(4):417-21, 2003.

Brann, C. R.; Brickley, M. R. \& Shepherd, J.P. Factors influencing nerve damage during lower third molar surgery. Br. Dent. J., 186(10):514-6, 1999.

Bueno, M. R.; Estrela, C.; Azevedo, B. C.; Brugnera Júnior, A. \& Azevedo, J. R. Tomografia computadorizada cone beam: revolução na odontologia. Rev. Assoc. Paul. Cir. Dent., 61(5):354-63, 2007.

Claeys, V. \& Wackens, G. Bifid mandibular canal: literature review and case report. Dentomaxillofac. Radiol., 34(1):55-8, 2005.

Dalili, Z.; Mahjoub, P. \& Sigaroudi, A. K. Comparison between cone beam computed tomography and panoramic radiography in the assessment of the relationship between the mandibular canal and impacted class C mandibular third molars. Dent. Res. J. (Isfahan), 8(4):203-10, 2011.

Devito, K. L. \& Tamburús, J. R. Anatomia do canal da mandíbula: classificação radiográfica das variações. Rev. Assoc. Paul. Cir. Dent., 55(4):261-6, 2001.

Fontoura, R. A.; Vasconcellos, H. A. \& Campos, A. E. Morphologic basis for the intraoral vertical ramus osteotomy: anatomic and radiographic localization of the mandibular foramen. J. Oral Maxillofac. Surg., 60(6):660-5, 2002.
Friedland, B.; Donoff, B. \& Dodson, T. B. The use of 3dimensional reconstructions to evaluate the anatomic relationship of the mandibular canal and impacted mandibular third molars. J. Oral Maxillofac. Surg., 66(8):1678-85, 2008.

Gülicher, D. \& Gerlach, K. L. Incidence, risk factors and follow-up of sensation disorders after surgical wisdom tooth removal. Study of 1,106 cases. Mund Kiefer Gesichtschir., 4(2):99-104, 2000.

Jhamb, A.; Dolas, R. S.; Pandilwar, P. K. \& Mohanty, S. Comparative efficacy of spiral computed tomography and orthopantomography in preoperative detection of relation of inferior alveolar neurovascular bundle to the impacted mandibular third molar. J. Oral Maxillofac. Surg., 67(1):58-66, 2009.

Koong, B.; Pharoah, M. J.; Bulsara, M. \& Tennant, M. Methods of determining the relationship of the mandibular canal and third molars: a survey of Australian oral and maxillofacial surgeons. Aust. Dent. J., 51(1):64-8, 2006.

Tantanapornkul, W.; Okouchi, K.; Fujiwara, Y.; Yamashiro, M.; Maruoka, Y.; Ohbayashi, N. \& Kurabayashi, T. A comparative study of cone-beam computed tomography and conventional panoramic radiography in assessing the topographic relationship between the mandibular canal and impacted third molars. Oral Surg. Oral Med. Oral Pathol. Oral Radiol. Endod., 103(2):253-9, 2007.

Langlais, R. P.; Broadus, R. \& Glass, B. J. Bifid mandibular canals in panoramic radiographs. J. Am. Dent. Assoc., 110(6):923-6, 1985.

Lindh, C.; Petersson, A. \& Klinge, B. Measurements of distances related to the mandibular canal in radiographs. Clin. Oral Implants Res., 6(2):96-103, 1995. 
Madeira, M. C. Anatomia da face. $5^{\text {a }}$ ed. São Paulo, Sarvier, 1995. pp. 174 .

Nakamori, K.; Fujiwara, K.; Miyazaki, A.; Tomihara, K.; Tsuji, M.; Nakai, M.; Michifuri, Y.; Suzuki, R.; Komai, K.; Shimanishi, M. \& Hiratsuka, H. Clinical assessment of the relationship between the third molar and the inferior alveolar canal using panoramic images and computed tomography. $J$. Oral Maxillofac. Surg., 66(11):2308-13, 2008.

Neves, F. S.; Rodrigues, V.; Burgos, V.; Oliveira, C.; Campos, P. S. F. \& Crusoé-Rebello, I. Variações anatômicas do canal mandibular observadas em radiografias panorâmicas: relato de casos. Int. J. Dent., 8(1):45-9, 2009.

Neves, F. S.; Souza, T. C.; de-Azevedo-Vaz, S. L.; Campos, P. S. F. \& Bóscolo, F. N. Influence of cone-beam computed tomography milliamperage settings on image quality of the mandibular third molar region. Oral Radiol., 30(1):27-31, 2014.

Nortjé, C. J.; Farman, A. G. \& Grotepass, F. W. Variations in the normal anatomy of the inferior dental (mandibular) canal: a retrospective study of panoramic radiographs from 3612 routine dental patients. Br. J. Oral Surg., 15(1):55-63, 1977.

Ohman, A.; Kivijärvi, K.; Blombäck, U. \& Flygare, L. Pre-operative radiographic evaluation of lower third molars with computed tomography. Dentomaxillofac. Radiol., 35(1):30-5, 2006.

Parks, E. T. Computed tomography applications for dentistry. Dent. Clin. North Am., 44(2):371-94, 2000.

Rodrigues, A. F. \& Vitral, R. W. F. Applications of computed tomography in dentistry. Pesqui. Bras. Odontopediatr. Clin. Integr., 7(3):317-24, 2007.

Rood, J. P. Permanent damage to inferior alveolar and lingual nerves during the removal of impacted mandibular third molars. Comparison of two methods of bone removal. Br. Dent. J., 172(3):108-10, 1992.

Rouas, P.; Nancy, J. \& Bar, D. Identification of double mandibular canals: literature review and three case reports with CT scans and cone beam CT. Dentomaxillofac. Radiol., 36(1):34-8, 2007.

Sanchis, J. M.; Peñarrocha, M. \& Soler, F. Bifid mandibular canal. J. Oral Maxillofac. Surg., 61(4):422-4, 2003.

Strietzel, F. P. \& Reichart, P. A. Wound healing after surgical wisdom tooth extraction. Evidence-based analysis. Mund Kiefer Gesichtschir., 6(2):74-84, 2002.

Suomalainen, A.; Ventä, I.; Mattila, M.; Turtola, L.; Vehmas, T. \& Peltola, J. S. Reliability of CBCT and other radiographic methods in preoperative evaluation of lower third molars. Oral Surg. Oral Med. Oral Pathol. Oral Radiol. Endod., 109(2):27684,2010
Tantanapornkul, W.; Okouchi, K.; Fujiwara, Y.; Yamashiro, M.; Maruoka, Y.; Ohbayashi, N. \& Kurabayashi, T. A comparative study of cone-beam computed tomography and conventional panoramic radiography in assessing the tomographic relationship between the mandibular canal and impacted third molars. Oral Sur. Oral Med. Oral Pathol. Oral Radiol. Endod., 103(2):253-9, 2007.

Wadu, S. G.; Penhall, B. \& Townsend, G. C. Morphological variability of the human inferior alveolar nerve. Clin. Anat., 10(2):82-7, 1997.

Xie, Q.; Wolf, J.; Soikkonen, K. \& Ainamo, A. Height of mandibular basal bone in dentate and edentulous subjects. Acta Odontol. Scand., 54(6):379-83, 1996.

Xie, Q.; Wolf, J.; Tievis R. \& Ainamo A. Resorption of mandibular canal wall in the edentulous aged population. J. Prosthet. Dent., 77(6):596-600, 1997.

\section{Correpondence to:}

Prof. Carla Cabral dos Santos Accioly Lins

Departament of Anatomy

Federal University of Pernambuco (UFPE)

Av. Prof. Moraes Rego s/n, Cidade Universitária

CEP: 50670-901

Recife-PE

BRAZIL

Email: cabralcarla1@hotmail.com.

Received: 12-08-2014

Accepted: 09-02-2015 